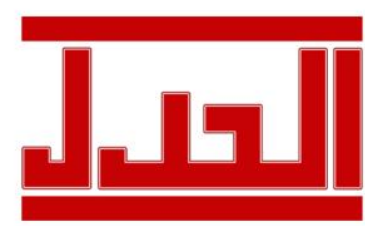

ISSN: $1979-4940$

E-ISSN: 2477-0124
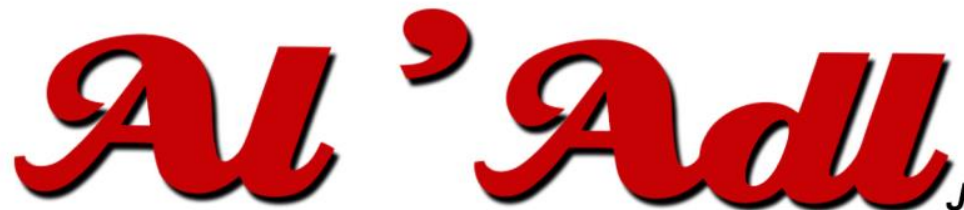

Jurnal Hukum

Editorial Office: Faculty of Law, Islamic University Of Kalimantan,

Jalan Adhyaksa No. 2 Kayutangi Banjarmasin, Kalimantan Selatan, Indonesia (70123)

Email: al_adl@uniska-bjm.ac.id

Web: http://ojs.uniska-bjm.ac.id

\title{
MEDIASI SEBAGAI ALTERNATIF PENYELESAIAN PERKARA TINDAK PIDANA PENIPUAN DI INDONESIA DITINJAU DARI ASAS CONTANTE JUSTICE
}

\author{
Dziky Saeful Rohim \\ Magister Ilmu Hukum Universitas Singaperbangsa Karawang \\ Jl. H.S. Ronggowaluyo Desa Puseurjaya Kecamatan Telukjambe Timur \\ Kabupaten Karawang Provinsi Jawa Barat Kode Pos : 41361 \\ Email: dzikyzharoo@gmail.com
}

$\begin{array}{ll}\text { Submitted } & : \text { 26 Desember 2020 } \\ \text { Revised } & : \text { 14 Januari 2021 } \\ \text { Accepted } & : \text { 15 Januari 2021 } \\ \text { Published } & : \text { 1 Februari 2021 }\end{array}$

\begin{abstract}
In the development of criminal law reform in various countries, there is a strong tendency to use penal mediation as an alternative to solving problems in the field of criminal law. Mediation is one of the efforts to settle criminal cases, especially criminal acts of fraud, which if seen as the act will cause harm to other people, it should be resolved by the mediation procedure. The problem is that the mediation procedure is not regulated in the Criminal Procedure Code or other statutory regulations related to criminal law enforcement. This becomes the basis for a new concept in resolving cases of criminal fraud based on restorative justice and for the realization of the principles of fast, simple and low cost trial. In this study, the authors used a normative juridical approach, namely an approach that was carried out by examining and interpreting theoretical matters concerning principles, conceptions, and legal comparisons. The results of the analysis and discussion in this study show that the government, especially the DPR, as the constitution-forming institution, especially the Law on Criminal Law, should immediately revise and include the mediation process as one of the resolutions of cases that can be resolved by means of deliberation to reach consensus. And soon the law was passed to replace the old KUHP and KUHAP because these laws were not in accordance with the developments in this modern era.
\end{abstract}

Keywords : Mediation; Fraud; Fast, Simple and Low Cost Principles.

Abstrak
Perkembangan pembaharuan hukum pidana di berbagai negara, ada kecenderungan kuat untuk menggunakan
mediasi pidana/penal sebagai salah satu alternatif penyelesaian masalah di bidang hukum pidana. Mediasi adalah
salah satu upaya penyelesaian perkara tindak pidana terutama tindak pidana penipuan yang jika dilihat
perbuatannya akan menimbulkan kerugian bagi orang lain maka sudah seharusnya dapat di selesaikan dengan
prosedur mediasi. Masalahnya adalah prosedur mediasi tidak diatur dalam KUHAP ataupun peraturan
perundang-undangan lainnya yang berkaitan dengan penegakan hukum pidana ini menjadi suatu landasan
konsep baru dalam menyelesaikan perkara-perkara tindak pidana penipuan berdasarkan keadilan restorative
justice dan demi terwujudnya asas peradilan cepat, sederhana dan biaya ringan. Pada penelitian ini penulis
menggunakan metode pendekatan yuridis normatif yaitu pendekatan yang dilakukan dengan cara menelaah dan
menginterpretasikan hal-hal yang bersifat teoritis yang menyangkut asas, konsepsi, dan perbandingan hukum.


Hasil analisis dan pembahasan pada penelitian ini bahwa pemerintah khususnya DPR sebagai lembaga pembentuk Undang-Undang terutama Undang-Undang tentang Hukum Pidana sebaiknya segera melakukan revisi dan memasukan proses mediasi sebagai salah satu penyelesaian perkara-perkara yang dapat diselesaikan dengan cara musyawarah mufakat. Dan segera undang-undang tersebut disahkan untuk mengganti KUHP dan KUHAP yang lama karena aturan hukum tersebut sudah tidak sesuai dengan perkembangan zaman era modern ini.

Kata Kunci : Mediasi, Tindak Pidana Penipuan, Asas cepat, Sederhana dan Biaya Ringan.

\section{PENDAHULUAN}

Mediasi adalah salah satu bentuk penyelesaian sengketa diluar lembaga peradilan (non litigasi) dengan bantuan orang lain atau pihak ketiga yang netral dan tidak memihak serta tidak sebagai pengambil keputusan yang disebut mediator. Tujuannya disini ialah untuk mencapai kesepakatan penyelesaian sengketa yang sedang mereka hadapi tanpa ada yang merasa dikalahkan. ${ }^{1}$ Penyelesaian persoalan hukum melalui mediasi bersifat win-win solution di mana para pihak tidak ada yang menang dan kalah, sehingga sengketa tidak berlangsung lama dan berlarut-larut serta dapat memperbaiki hubungan antar para pihak yang bersengketa, Keuntungan penyelesaian suatu sengketa dengan menggunakan mediasi sangat banyak diantaranya biaya murah, cepat, proses sederhaha, memuaskan para pihak yang bersengketa karena bersifat kooperatif, mencegah menumpuknya perkara dipengadilan, menghilangkan dendam, memperteguh hubungan silaturahmi dan dapat memperkuat serta memaksimalkan fungsi lembaga peradilan dalam penyelesaian sengketa disamping proses pengadilan yang bersifat memutus (Ajudikatif). ${ }^{2}$

Penyelesaian sengketa di Indonesia sepenuhnya menjadi kewenangan pengadilan. Setiap ada sengketa, pengadilanlah yang menentukan bagaimana keputusan atau penetapannya. Hal ini memang sesuai dengan aturan perundang-undangan yang berlaku, karena semua sengketa diselesaikan melalui pengadilan. Indonesia menyiapkan Hukum Acara dengan sangat ketat bahkan hukum formil itu dimasukkan ke dalam hukum publik. Di samping itu juga dalam bidang hukum acara Perdata disebutkan hakim atau pengadilan harus bersikap pasif, hanya menunggu keluhan dan tuntutan pihak yang berkepentingan sebab tanpa tuntutan, pengadilan tidak dapat berbuat apapun. Disebutkan pula hakim cukup menemukan

${ }^{1}$ I Ketut Artadi dan Dewa Nyoman Rai Asmara Putra, 2009, Pengantar Umum Tentang Alternatif Penyelesaian Sengketa dan Perancangan Kontrak, Denpasar, Fakultas Hukum Universitas Udayana, hlm. 12.

${ }^{2}$ I Made Agus Mahendra Iswara, 2011, "Peranan Mediasi Penal dalam Menyelesaikan Tindak Pidana Kekerasan dalam Rumah Tangga (KDRT) di Polresta Denpasar”, Skripsi, Fakultas Hukum Universitas Udayana, hlm. 6. Lihat juga Yati Nurhayati, The Finality of Arbitration : The Pros and Cons of The Court's Power To Setting Aside Arbitral Awards In Indonesia, Prosiding International Legal Recontruction in Indonesia Based on Human Rights, Unissula Press, 2019, hlm. 376-377. 
kebenaran formal saja. Akan tetapi akhir-akhir ini telah muncul pola penyelesaian, melalui tawar menawar penyelesaian, yang kadang kala telah dirancang sebelum mereka bersengketa, yang disebut mediasi. Cara seperti ini pula dapat mengurangi beban pengadilan Negeri, Pengadilan Tinggi dan Mahkamah Agung.

Perkara pidana pada prinsipnya tidak dapat diselesaikan melalui mekanisme Mediasi. Namun dalam praktek, sering juga perkara pidana diselesaikan melalui mekanisme mediasi, yang merupakan inisiatif penegak hukum sebagai bagian dari penyelesaian perkara. Dengan demikian, Pada kenyataannya mediasi sebenarnya dapat dijalankan dalam Sistem Peradilan Pidana. Negara-negara yang telah menerapkan hal tersebut ialah Austria, Jerman, Belgia, Perancis, Polandia, Slovenia, Canada, Amerika Serikat, Norwegia, Denmark, dan Finlandia. Mediasi inilah yang disebut sebagai Mediasi Penal. ${ }^{3}$ Menurut DS. Dewi dan Fatahillah A. Syukur, Mediasi Penal adalah Penyelesaian perkara pidana melalui musyawarah dengan bantuan mediator yang netral, dihadiri korban dan pelaku beserta orang tua dan perwakilan masyarakat, dengan tujuan pemulihan bagi korban, pelaku, dan lingkungan masyarakat. ${ }^{4}$

Berkaitan dengan Tindak Pidana Penipuan yang merupakan salah satu perilaku atau tindakan tercela dan tidak sesuai dengan norma (hukum) yang berlaku. Seiring perkembangan zaman, perbuatan tercela seperti penipuan sangat marak terjadi, karena perbuatan ini tidaklah terlalu sulit untuk dilakukan. Yang perlu dilakukan oleh si penipu hanyalah meyakinkan korban dengan kata-kata bohong agar korban mengikuti apa kata dan keinginan si pelaku penipuan. Kenyataan di lapangan membuktikan bahwa tindak pidana penipuan seringkali dipersamakan dengan ingkar janji dalam hukum perdata (wanprestasi), sehingga aparat penegak hukum, utamanya penuntut umum seringkali keliru dalam menentukan yang mana yang merupakan tindak pidana penipuan dan wanprestasi dalam membuat surat dakwaan, sehingga tidak jarang Majelis Hakim memutus lepas perkara yang dianggap sebagai tindak pidana penipuan oleh penuntut umum, akan tetapi sebenarnya perbuatan tersebut masuk dalam ranah hukum perdata.

Berdasarkan Undang-Undang Nomor 8 Tahun 1981 tentang Pengaturan Hukum Acara Pidana (KUHAP) Penyelesaian Perkara tindak pidana penipuan secara Mediasi (Non Litigasi) tidak diatur, kecuali dari perkara tentang pelanggaran lalu lintas, akan tetapi kenyataannya di masyarakat menunjukkan bahwa sering dijumpai perkara pidana penipuan dapat diselesaikan

\footnotetext{
${ }^{3}$ Mansyur Ridwan, 2010, Mediasi Penal Terhadap Perkara KDRT (Kekerasan Dalam Rumah Tangga), Jakarta, Yayasan Gema Yustisia Indonesia, hlm. 166.

4 DS. Dewi dan Fatahillah A. Syukur, 2011, Mediasi Penal : Penerapan Restorative Justice di Pengadilan Anak Indonesia, Depok, Indie-Publishing, hlm. 86.
} 
melalui kompromi atau kesepakatan antara tersangka dan korban atau keluarganya dengan melibatkan polisi atau advokat atau perangkat desa bahkan pemuka masyarakat sebagai mediator.

Dalam perkembangan pembaharuan hukum pidana di berbagai negara, ada kecenderungan kuat untuk menggunakan mediasi pidana/penal sebagai salah satu alternatif penyelesaian masalah di bidang hukum pidana. Menurut Detlev Frehsee, meningkatnya penggunaan restitusi dalam proses pidana menunjukkan, bahwa perbedaan antara hukum pidana dan perdata tidak begitu besar dan perbedaan itu menjadi tidak berfungsi. ${ }^{5}$

Asas Contante Justice bertujuan untuk memberikan kepastian prosedural bagi tersangka dan/atau terdakwa yang menjalankan proses peradilan pidana. Asas ini juga dikenal dengan asas peradilan cepat, sederhana dan biaya ringan. Dalam Surat Edaran Mahkamah Agung Nomor 6 Tahun 1992 tentang Penyelesaian Perkara di Pengadilan Tinggi dan Pengadilan Negeri menyatakan bahwa pelaksanaan peradilan hendaklah dilakukan dengan cepat, sederhana dan biaya ringan sebab peradilan hendaklah memenuhi harapan dari pencari keadilan yang mengharapkan adanya peradilan yang cepat dan adil serta biaya yang ringan. ${ }^{6}$ Asas ini juga disebutkan dalam Pasal 2 ayat (4) Undang-Undang Nomor 48 Tahun 2009 tentang Kekuasaan Kehakiman bahwa Asas sederhana mengadung arti pemeriksaan dan penyelesaian perkara dilakukan dengan cara yang efisien dan efektif. Asas cepat, asas yang bersifat universal yang berkaitan dengan waktu penyelesaian yang tidak berlarut-larut. Asas cepat ini dikenal denga adegium justice delayed justice denied, yakni proses peradilan yang lambat tidak akan memberikan keadilan kepada para pihak. Asas biaya ringan mengandung arti biaya dapat dijangkau oleh masyarakat. ${ }^{7}$

Dalam berupaya menerapkan asas peradilan cepat, sederhana dan biaya ringan menurut saya upaya mediasi ini perlu diterapkan dan diatur dalam pembaharuan hukum acara pidana. Karena proses peradilan non litigasi tetap menjadi pilihan terbaik dan berkualitas jika dibandingkan proses peradilan litigasi yang memakan waktu lama, biaya mahal proses panjang dari mulai penyelidikan, penyidikan, penuntutan, peradilan pada tingkat pertama, banding, kasasi sampai dengan peninjauan kembali, dan itu lebih rumit.

\footnotetext{
${ }^{5}$ Detlev Frehsee (Professor of Criminology and Criminal Law, University of Bielefeld, Germany), 2019, "Restitution and Offender-Victim Arrangement in German Criminal Law: Development and Theoretical Implications", http://wings.buffalo.edu/law/ bclc/bclr.htm, [diakses tanggal 28 Juni 2011].

${ }^{6}$ Ferdinan Loiles Haslim, Penerapan Diversi Dalam Tahap Penyidikan Terhadap Anak Pelaku Tindak Pidana Berdasarkan Undang-Undang Nomor 11 Tahun 2012 tentang Sistem Peradilan Pidana Anak di Wilayah Hukum Polresta Barelang, Skripsi Fakultas Hukum Universitas Internasional Batam, UIB Repository, hlm. 19.

7 Muhammad Yasin, https://hukumonline.com, Reformasi Peradilan : Peradilan yang Sederhana, Cepat dan Biaya Ringan, diakses pada Tanggal 04 Februari 2018.
} 
Berdasarkan latar belakang masalah diatas maka yang penulis berusaha mengkaji dan memahami dalam penelitian yang berjudul : "Mediasi Sebagai Alternatif Penyelesaian Perkara Tindak Pidana Penipuan Ditinjau Dari Asas Contante Justice".

\section{RUMUSAN MASALAH}

Berdasarkan latar belakang masalah diatas maka masalah yang dapat dirumuskan adalah tentang bagaimanakah Penerapan mediasi sebagai Alternatif Penyelesaian Perkara Tindak Pidana Penipuan di Indonesia dalam mewujudkan asas peradilan Contante Justice ?

\section{METODE PENELITIAN}

Pembuatan sebuah karya ilmiah terutama karya ilmiah penelitian hukum diharuskan menggunakan metode penelitian hukum. Ilmu hukum berusaha untuk menampilkan hukum secara integral sesuai dengan kebutuhan kajian ilmu hukum itu sendiri, sehingga metode penelitian dibutuhkan untuk memperoleh arah penelitian yang komprehensif. ${ }^{8}$ Sebenarnya ilmu hukum mempunyai ciri-ciri sebagai ilmu yang bersifat preskriptif dan terapan. Dalam preskriptif, ilmu hukum mempelajari tujuan hukum, nilai-nilai keadilan dalam suatu hukum, baik buruk suatu aturan hukum, konsep-konsep dan norma hukum. sedangkan dalam ilmu terapan, ilmu hukum menetapkan suatu prosedur, ketentuan-ketentuan dan batasan-batasan dalam menegakan suatu aturan hukum. ${ }^{9}$

Penelitian tentang Mediasi sebagai upaya alternatif penyelesaian perkara tindak pidana penipuan di Indonesia adalah penelitian yang menggunakan metode pendekatan yuridis normatif yaitu pendekatan yang dilakukan dengan cara menelaah dan menginterpretasikan hal-hal yang bersifat teoritis yang menyangkut asas, konsepsi, dan perbandingan hukum. ${ }^{10}$ Jenis penelitian yang digunakan dalam penelitian ini adalah jenis penelitian kualitatif yaitu penelitian yang dimaksudkan untuk memahami fenomena tentang apa yang dialami oleh subyek penelitian, misalnya seperti tindakan, konsepsual hukum maupun perbandingan hukum dan lainnya yang secara holistic dideskripsikan dalam bentuk kata-kata naratif pada suatu konteks khusus alamiah dan dengan memanfaatkan metode ilmiah. Bahan hukum yang dikaji dan yang dianalisis dalam penelitian ini menggunakan data sekunder, meliputi:

\footnotetext{
${ }^{8}$ Yati Nurhayati, "Perdebatan Metode Normatif dengan Metode Empirik Dalam Penelitian Ilmu Hukum Ditinjau Dari Karakter, Fungsi dan Tujuan Ilmu Hukum”, Jurnal Al Adl, Volume 5 Npmor 10, 2013. hlm. 15.

${ }^{9}$ Yati Nurhayati, Pengantar Ilmu Hukum, Nusa Media, Bandung, 2020. hlm. 9.

${ }^{10}$ Kornelius Benuf dan Muhamad Azhar, 2020, "Metodologi Penelitian Hukum Sebagai Instrumen Instrumen Mengurangi Permasalahan Hukum Kontemporer”, Jurnal Gema Keadilan, Volume 7, Edisi I, hlm. 24.
} 
a. Bahan hukum primer. Bahan hukum primer merupakan bahan hukum yang bersifat authoritative, artinya mempunyai otoritas. Bahan-bahan hukum primer terdiri atas peraturan perundang-undangan, catatan-catatan resmi atau risalah dalam pembentukan peraturan perundang-undangan, yaitu :

1). Undang-undang Dasar NRI Tahun 1945;

2). Kitab Undang-Undang Hukum Pidana Indonesia;

3). Kitab Undang-Undang Hukum Perdata Indonesia;

4). Undang-Undang Nomor 8 Tahun 1981 Tentang Kitab Undang Undang Hukum Acara Pidana;

5). Undang-Undang Nomor 30 Tahun 1999 tentang Arbitrase dan Alternatif Penyelesaian Sengketa;

6). Undang-Undang Nomor 17 Tahun 2007 tentang Rencana Pembangunan Jangka Panjang Tahun 2005-2025;

7). Undang-Undang Nomor 11 Tahun 2008 tentang Informasi dan Transakasi Elektronik;

8). Undang-Undang Nomor 19 Tahun 2016 tentang Perubahan Atas Undang-Undang Nomor 11 Tahun 2008 tentang Informasi dan Transakasi Elektronik;

9). Surat Edaran Mahkamah Agung Nomor 6 Tahun 1992 tentang Penyelesaian Perkara di Pengadilan Tinggi dan Pengadilan Negeri; dan

10). Peraturan Kepala Kepolisian Republik Indonesia Nomor 6 Tahun 2019 tentang Penyidikan Tindak Pidana Mewajibkan Adanya Proses Mediasi Dalam Setiap Penanganan Tindak Pidana.

b. Bahan hukum sekunder. Bahan hukum sekunder berupa dokumen-dokumen resmi, meliputi buku, jurnal hukum, makalah, Artikel, Jurnal, majalah, surat kabar dan lainnya.

Bahan hukum tersier. Bahan hukum tersier merupakan bahan hukum yang memberikan petunjuk maupun penjelasan terhadap bahan hukum primer dan bahan hukum sekunder, berupa kamus hukum, kamus bahasa Indonesia, dan sebagainya

\section{PEMBAHASAN}

\section{Penerapan Mediasi Sebagai Alternatif Penyelesaian Perkara Tindak Pidana Penipuan Di Indonesia Dalam Upaya Mewujudkan Asas Peradilan Contante Justic}

Menurut Kitab Undang-Undang Hukum Acara Pidana di Indonesia perkara pidana tidak dapat diselesaikan diluar proses pengadilan, akan tetapi dalam hal-hal tertentu dimungkinkan pelaksanaanya. Dalam praktiknya penegakan hukum pidana di Indonesia, walaupun Kitab Undang-Undang Hukum Pidana dan Kitab Undang-Undang Hukum Acara Pidana atau Undang-Undang Tindak Pidana Pidana lainnya yang diatur secara khusus dalam Undang-Undang tersendiri tidak mengatur adanya proses penyelesaian tindak pidana secara mediasi tetapi dalam prakteknya sering ditemukan diselesaikan diluar proses pengadilan melalui diskresi aparat penegak hukum, mekanisme perdamaian, lembaga adat dan 
sebagainya. Konsekuensi makin diterapkan eksistensi mediasi penal sebagai salah satu alternatif penyelesaian perkara dibidang hukum pidana melalui restitusi dalam proses pidana menunjukkan, bahwa perbedaan antara hukum pidana dan perdata tidak begitu besar dan perbedaan itu menjadi tidak berfungsi. ${ }^{11}$

Mediasi Penal adalah suatu langkah penegekakan hukum yang menerapkan nilai-nilai Keadilan Restoratif, malahan sekarang keadilan ini dikatakan sebagai pendekatan yang Progresif seperti yang disampaikan oleh Marc Levin "Pendekatan yang dulu dinyatakan usang, kuno dan tradisional dikatakan sebagai pendekatan yang progresif". ${ }^{12}$ Menurut Barda Nawawi Arief, Alasan dipergunakan mediasi penal dalam penyelesaian perkara pidana adalah karena ide dari mediasi penal berkaitan dengan masalah pembaharuan hukum pidana (Penal Reform), berkaitan juga dengan masalah pragmatisme, alasan lainnya adalah adanya ide perlindungan korban, ide harmonisasi, ide restorative justice, ide mengatasi kekakuan (formalitas) dan efek negatif dari sistem peradilan pidana dan sistem pemidanaan yang berlaku, serta upaya pencarian upaya alternatif pemidanaan (selain penjara). ${ }^{13}$ Sebenarnya masyarakat Indonesia dalam menyelesaikan suatu perkara baik perdata maupun pidana dengan Mediasi Penal bukan hal baru, hal ini dibuktikan dengan adanya penyelesaian dengan pendekatan musyawarah. Bila dilihat secara historis kultur (budaya) masyarakat Indonesia sangat menjunjung tinggi pendekatan konsens, ${ }^{14}$ yang lebih mengutamakan pengambilan keputusan secara tradisional dan penyelesaian melalui mekanisme adat. Ada juga yang melalukan penelitian mengenai mediasi penal dalam tindak pidana lingkungan hidup ${ }^{15}$ atau mediasi penal dan perkara pidana malpraktik dokter. ${ }^{16}$

Terkait dengan Tindak Pidana Penipuan bahwa perbuatan tersebut termasuk kedalam rumusan tindak pidana didalam KUHP, namun demikian rumusan penipuan dalam KUHP bukan merupakan suatu definisi melainkan hanyalah untuk menetapkan unsur-unsur suatu

11 Barda Nawawi Arief, 2008, Mediasi Penal Penyelesaian Perkara Diluar Pengadilan, Semarang, Pustaka Magister, hlm. 4-5.

${ }_{12}$ Marc Levin dalam Eva Achjani Zulfa, 2011, Pergeseran Paradigma Pemidanaan, Bandung, Lubuk Agung, hlm. 67.

${ }^{13}$ Barda Nawawi Arief, 2000, Kebijakan Legislatif dalam Penanggulangan Kejahatan dengan Pidana Penjara, Semarang, Badan Penerbit Universitas Diponogoro, hlm. 169-171.

${ }^{14}$ Mushadi, 2007, Mediasi dan Resolusi Konflik di Indonesia, Semarang, Walisongo Mediation Center, hlm. 38 .

${ }^{15}$ Nirmala Sari, Diana Haiti dan Ifrani, "Mediasi Penal Sebagai Alternatif Penyelesaian Perkara Tindak Pidana Lingkungan Hidup Pada Lahan Basah di Provinsi Kalimantan Selatan", Jurnal Al Adl, Volume VIII Nomor 1, Januari-April 2016, hlm. 2-7.

${ }^{16}$ Yati Nurhayati, "The Application of Balance idea In Settlement of Doctor Malpractice Case Through Penal Mediation", The 2nd Proceeding “Indonesia Clean of Corruption in 2020, Unissula Press, hlm. 111-117. 
perbuatan sehingga dapat dikatakan sebagai penipuan dan pelakunya dapat dipidana. Pasal 378 menyatakan bahwa "Barang siapa dengan maksud untuk menguntungkan diri sendiri atau orang lain secara melawan hak, mempergunakan nama palsu atau sifat palsu ataupun mempergunakan tipu muslihat atau susunan kata-kata bohong, menggerakan orang lain untuk menyerahkan suatu benda atau mengadakan suatu perjanjian hutang atau meniadakan suatu piutang, karena salah telah melakukan penipuan, dihukum dengan hukuman penjara selama-lamanya empat tahun".

Seiring Perkembangan Zaman Tindak Pidana Penipuan juga diatur dalam Pasal 28 ayat (1) Undang-Undang Nomor 19 Tahun 2016 tentang Perubahan Atas Undang- Undang Nomor 11 Tahun 2008 tentang Informasi dan Transaksi Elektronik yang menyatakan bahwa "Setiap orang dengan sengaja, dan tanpa hak menyebarkan berita bohong dan menyesatkan yang mengakibatkan kerugian konsumen dalam Transaksi Elektronik”. Suseno berpendapat bahwa "Unsur-unsur di dalam Pasal 28 ayat (1) Undang-Undang Nomor 19 Tahun 2016 tentang Perubahan Atas Undang- Undang Nomor 11 Tahun 2008 tentang Informasi dan Transaksi Elektronik, identik dan memiliki beberapa kesamaan pada tindak pidana penipuan konvensional yang diatur dalam Pasal 378 KUHP dan memiliki karakteristik khusus yaitu telah diakuinya bukti, media elektronik, dan adanya perluasan yurisdiksi dalam UndangUndang Nomor 19 Tahun 2016 tentang Perubahan Atas Undang- Undang Nomor 11 Tahun 2008 tentang Informasi dan Transaksi Elektronik". ${ }^{17}$

Tindak pidana penipuan merupakan tindak pidana biasa yang berdasarkan KUHAP harus di proses peradilan dan dijatuhi hukuman berdasarkan Pasal 378 KUHP atau Pasal 28 ayat (1) Undang-Undang tentang ITE. Akan tetapi menurut Barda Nawwawi Arief yang mengemukakan bahwa upaya penanggulangan kejahatan secara garis besar dapat dikelompokan mnjadi dua, yaitu melalui jalur "penal" (hukum acara pidana) yang menitikberatkan pada tindakan yang bersifat "represif" (penindakan, pemberantasan, dan penumpasan) setelah kejahatan itu terjadi, dan menggunakan jalur "non-penal" (diluar hukum acara pidana) lebih menitikberatkan pada sifat "preventif" (pencegahan, penangkalan, pengendalian) sebelum kejahatan itu terjadi. ${ }^{18}$ Pada pembahasan ini penulis akan membahas penyelesaian tindak pidana penipuan melalui jalur nonpenal atau jalur diluar pengadilan pidana. Penanggulangan atau penyelesaian secara jalur nonpenal, mempunyai tujuan yaitu

\footnotetext{
${ }^{17}$ Sigid Suseno, 2012, Yurisdiksi Tindak Pidana Siber, Bandung, PT. Refika Aditama, hlm. 171.

${ }^{18}$ Barda Nawawi Arief, 1996, Bunga Rampai Kebijakan Hukum Pidana, Bandung, Citra Aditya Bakti, hlm. 49.
} 
penyadaran untuk meningkatkan kesadaran hukum untuk mencegah perbuatan yang dapat merugikan masyarakat. Penyelesaian diluar pengadilan biasanya melalui proses mediasi dalam Alternatif Penyelesaian Sengketa.

Contoh Kasus terjadi wilayah Kabupaten Karawang bulan mei pada tahun 2019 yang pada waktu itu penulis adalah sebagai saksi yang melihat langsung perjanjian bisnis jualan sayur antara pihak Korban sebagai pemodal dan pihak terlapor sebagai pengelola bisnis. Kasus terjadi di awal bulan ramadhan yang menyatakan bahwa pelaku hendak bekerjasama dengan pelapor sebagai pemodal untuk membuka usaha dipasar induk cikopo purwakarta yaitu toko sayuran. Singkat cerita bahwa pelaku akan memberikan laba hasil jualannya tersebut kepada pemodal setiap bulan. Akan tetapi selama tiga bulan berturut turut pelaku tidak memberikan apapun termasuk modal. Akhirnya pelapor merasa di tipu dengan kerugian 200 juta rupiah dan melaporkan kejadian tersebut kepada Polsek setempat. Akhir pelaku dipanggil dan dimintai pertanggungjawaban atas perbuatannya yang diduga melanggar pasal 378 KUHP. Akan tetapi pelaku berjanji akan mengembalikan segala kerugian pelapor termasuk hasil keuntungan dari jualannya yang telah dijanjikan pelaku sebelumnya dan pada akhir pelapor menerima dan akan di selesaikan dengan mediasi. Tindakan penyidik pada waktu itu pun menghentikan proses penyidikan kasus tersebut yang seharusnya berdasarkan perintah KUHAP dan alat buktinya lengkap maka seharusnya proses penyidikan tersebut dilanjutkan ke proses persidangan walaupun pelapor telah mencabut laporannya. Akan tetapi jika penyidik mengacu pada Pasal 12 Peraturan Kepala Kepolisian Negara Republik Indonesia Nomor 6 Tahun 2019 tentang Penyidikan Tindak Pidana yang menyatakan bahwa, "Dalam proses penyidikan dapat dilakukan keadilan restoratif, apabila terpenuhi syarat materiil, meliputi:

a. Tidak menimbulkan keresahan masyarakat atau tidak ada penolakan masyarakat;

b. Tidak berdampak konflik sosial;

c. Adanya pernyataan dari semua pihak yang terlibat untuk tidak keberatan, dan melepaskan hak menuntutnya di hadapan hukum;

d. Prinsip pembatas:

1). pada pelaku:

a) tingkat kesalahan pelaku relatif tidak berat, yakni kesalahan dalam bentuk kesengajaan; dan

b) pelaku bukan residivis;

2). pada tindak pidana dalam proses :

a) penyelidikan; dan

b) penyidikan, sebelum SPDP dikirim ke Penuntut Umum;

Formil, meliputi: 
c. Surat permohonan perdamaian kedua belah pihak (pelapor dan terlapor);

d. Surat pernyataan perdamaian (akte dading) dan penyelesaian perselisihan para pihak yang berperkara (pelapor, dan/atau keluarga pelapor, terlapor dan/atau keluarga terlapor dan perwakilan dari tokoh masyarakat) diketahui oleh atasan Penyidik;

e. Berita acara pemeriksaan tambahan pihak yang berperkara setelah dilakukan penyelesaian perkara melalui keadilan restoratif;

f. Rekomendasi gelar perkara khusus yang menyetujui penyelesaian keadilan restoratif; dan

g. Pelaku tidak keberatan dan dilakukan secara sukarela atas tanggung jawab dan ganti rugi.

Secara materiil dan formil proses penyidikan berdasarkan keadilan restoratif dari Peraturan Kepala Kepolisian Negara Republik Indonesia Nomor 6 Tahun 2019 tentang Penyidikan Tindak Pidana, maka sudah sepatutnya tindakan penyidik pada kasus diatas sudah tepat. Karena secara materiil dan formil unsur dari Pasal 12 Peraturan Kepala Kepolisian Negara Republik Indonesia Nomor 6 Tahun 2019 tentang Penyidikan Tindak Pidana telah terpenuhi.

Dalam kasus lain terjadi adalah kasus-kasus tindak pidana penipuan secara online. Penipuan dengan modus penjualan handphone dan elektronik via online marak terjadi di Facebook akhir-akhir ini, dengan mengaku barang BM (Black Market) dari Batam serta harga yang jauh lebih murah dari harga pasaran membuat banyak orang tertarik untuk memesan barang yang ditawarkan. Dan pernah juga terjadi di karawang jual beli mobil Online yang pada akhirnya diselesaikan melalui jalur mediasi setelah dilaporkan kepada pihak kepolisian setempat. dari kedua kasus tersebut memberikan kita gambaran bahwa penerapan proses penyelesaian perkara tindak pidana penipuan walaupun secara aturan formil tindakan tersebut tidak dapat di selesaikan melalui proses non litigasi akan tetapi pada kenyataan justru mediasi merupakan alternatif penyelesaian perkara tindak pidana penipuan yang sangat memenuhi asas peradilan cepat, sederhana dan biaya ringan. hal ini tentu dapat diselesaikan dengan proses mediasi karena tindak pidana penipuan merupakan perkara yang berkaitan erat dengan para pihak, artinya antara pelaku dan korban lebih banyak memiliki urusan dibandingkan dengan perkara pidana lain yang menjadi (sebagian besar) urusan negara karena mengganggu ketentraman dan ketertiban, sehingga dikatakan sebagai perkara quasi perdata-pidana, karena ada unsur perdata dalam penyelesaian perkara pidana. Penyelesaian perkara pidana melalui jalur mediasi ini harus didasari pada kesepakatan antara korban dan pelaku. Inisiatif 
penggunaan jalur ini bisa datang dari korban, pelaku maupun polisi atau penasehat hukum dan tokoh masyarakat ataupun tokoh adat.

Pengembangan model alternatif penyelesaian secara mediasi ini disebabkan karena model yang selama ini ada (model litigasi) mengandung banyak kelemahan sehingga keadilan yang didambakan oleh pelaku dan korban tak muncul. Model penyelesaian perkara pidana penipuan melalui jalur non litigasi dapat mengurangi benang kusut pada Sistem Peradilan Pidana dengan memutus perkara pidana melalui cara-cara yang dipakai dalam hukum perdata. Hukum pidana didasarkan pada tujuan dari Sistem Peradilan Pidana, yaitu menemukan kebenaran dan keadilan serta memecahkan masalah kejahatan. Berdasarkan kajian teoretis pun, penggunaan cara ini memberi keuntungan, baik bagi korban maupun pelaku kejahatan. Melihat keuntungan dan kelebihan dari model ini maka sudah selayaknya diakomodasi dan dipraktekkan dalam Sistem Peradilan Pidana yang terpadu (integrated criminal justice system).

Selain Tindak Pidana Penipuan ada perkara-perkara tindak pidana lainnya yang dapat menggunakan jalur mediasi diantaranya adalah sebagaimana yang diatur dalam Pasal 310 KUHP (penghinaan/pencemaran nama baik), Pasal 311 KUHP (fitnah), Pasal 351 KUHP (penganiayaan), Pasal 352 ayat (1) KUHP (penganiyaan ringan), Pasal 359 KUHP (karena kealpaan menyebabkan matinya orang), Pasal 372 KUHP (penggelapan). Selain perkaraperkara tersebut di atas, perkara pidana yang diatur dalam dalam Pasal 285 KUHP (perzinahan), Pasal 332 KUHP (melarikan gadis di bawah umur), Pasal 367 ayat (2) KUHP (pencurian yang dilakukan oleh anggota keluarga), juga dapat diselesaikan dengan jalur itu. Beberapa perkara pidana di luar KUHP yang pernah dilakukan penyelesaian melalui jalur non litigasi adalah pemalsuan merek (Undang-Undang Nomor 20 Tahun 2016 tentang Merek), Kekerasan Dalam Rumah Tangga/KDRT (Undang-Undang Nomor 23 Tahun 2004 tentang Penghapusan Kekerasan Dalam Rumah Tangga), dan money politic (undang-Undang Nomor 8 Tahun 2012 tentang pemilihan Umum Anggota DPR, DPD, DPRD).

\section{PENUTUP}

\section{A. Kesimpulan}

Berdasarkan hasil dan pembahasan diatas maka dapat disimpulkan bahwa Penerapan mediasi sebagai Alternatif Penyelesaian Perkara Tindak Pidana Penipuan di Indonesia dalam mewujudkan asas peradilan Contante Justice, bahwa Mediasi dapat dipergunakan dalam 
menyelesaikan perkara pidana terutama perkara tindak pidana penipuan demi mewujudkan asas peradilan cepat, sederhana dan biaya ringan, maka penerapan penyelesaian dengan mediasi merupaka kerangka konsep bagi penegakan hukum yang lebih cepat, efektif, efisien dan sesuai harapan bangsa dan Negara.. Penerapan mediasi dalam perkara pidana merupakan penjabaran nilai-nilai keadilan restoratif yang berorientasi pada penyelesaian perkara yang menguntungkan semua pihak (korban, pelaku, dan pihak ketiga yaitu masyarakat).

\section{B. Saran}

Saran yang dapat penulis berikan dengan adanya hasil penelitian ini adalah :

1. Diharapkan Dewan Perwakilan Rakyat sebagai Dewan pembentukan dan perumusan dari undang-undang Nasional terutama dalam pembentukan undang-undang hukum pidana nasional, selalu memperhatikan nilai nilai keadilan restoratif, asas-asas hukum pidana baik asas peradilan pidana maupun asas hukum pidana materiilnya.

2. Diharapkan KUHP dan KUHAP ke depan dapat memenuhi unsur keadilan sosial bagi seluruh rakyat Indonesia.

3. Diharapkan agar sistem Restoratif Justice dan mediasi penal dapat segera dilaksanakan dalam sistem peradilan pidana di Indonesia dengan aturan hukum yang pasti. Agar kedepannya permasalahan pidana mendapat tempat di mata pencari kebenaran, karena saat ini sistem hukum di Indonesia masih mengacu pada KUHP dan KUHAP yang lama dan sulit bagi mereka yang mencari keadilan dan kepastian hukum yang berlandaskan pada asas peradilan "Cepat, Murah dan Sederhana (Asas peradilan Contante Justice)". Serta untuk mengurangi penumpukan perkara di tingkat pertama (Pengadilan Tingkat Pertama) sampai tingkat Mahkamah Agung, yang mana setiap tahun banyak kasus yang menjadi PR bagi Mahkamah Agung.

\section{Buku}

\section{DAFTAR PUSTAKA}

Barda Nawawi Arief, (1996), Kebijakan Hukum Pidana, Bandung, Citra Aditya Bakti.

Barda Nawawi Arief, (2000), Kebijakan Legislatif dalam Penanggulangan Kejahatan dengan Pidana Penjara, Semarang, Badan Penerbit Universitas Diponogoro.

Barda Nawawi Arief, (2008), Mediasi Penal Penyelesaian Perkara Diluar Pengadilan, Semarang, Pustaka Magister. 
DS. Dewi dan Fatahillah A. Syukur, (2011), Mediasi Penal : Penerapan Restorative Justice di Pengadilan Anak Indonesia, Depok, Indie-Publishing.

Mansyur Ridwan, (2010), Mediasi Penal Terhadap Perkara KDRT (Kekerasan Dalam Rumah Tangga), Jakarta, Yayasan Gema Yustisia Indonesia.

Marc Levin dalam Eva Achjani Zulfa, (2011), Pergeseran Paradigma Pemidanaan, Bandung, Lubuk Agung.

Mushadi, (2007), Mediasi dan Resolusi Konflik di Indonesia, Semarang, Walisongo Mediation Center.

Sigid Suseno, (2012), Yurisdiksi Tindak Pidana Siber, Bandung, PT. Refika Aditama.

Yati Nurhayati, Pengantar Ilmu Hukum, Nusa Media, Bandung, 2020.

\section{Peraturan Perundang-Undangan}

Undang-Undang Dasar Negara Republik Indonesia Tahun 1945.

Kitab Undang-Undang Hukum Pidana Indonesia.

Kitab Undang-Undang Hukum Perdata Indonesia.

Undang-Undang Nomor 8 Tahun 1981 Tentang Kitab Undang Undang Hukum Acara Pidana

Undang-Undang Nomor 30 Tahun 1999 tentang Arbitrase dan Alternatif Penyelesaian Sengketa.

Undang-Undang Nomor 17 Tahun 2007 tentang Rencana Pembangunan Jangka Panjang Tahun 2005-2025.

Undang-Undang Nomor 11 Tahun 2008 tentang Informasi dan Transakasi Elektronik.

Undang-Undang Nomor 19 Tahun 2016 tentang Perubahan Atas Undang-Undang Nomor 11 Tahun 2008 tentang Informasi dan Transakasi Elektronik.

Peraturan Kepala Kepolisian Republik Indonesia Nomor 6 Tahun 2019 tentang Penyidikan Tindak Pidana Mewajibkan Adanya Proses Mediasi Dalam Setiap Penanganan Tindak Pidana

Surat Edaran Mahkamah Agung Nomor 6 Tahun 1992 tentang Penyelesaian Perkara di Pengadilan Tinggi dan Pengadilan Negeri

\section{Jurnal}

Ferdinan Loiles Haslim, (2019), Penerapan Diversi Dalam Tahap Penyidikan Terhadap Anak Pelaku Tindak Pidana Berdasarkan Undang-Undang Nomor 11 Tahun 2012 
tentang Sistem Peradilan Pidana Anak di Wilayah Hukum Polresta Barelang, Skripsi Fakultas Hukum Universitas Internasional Batam, UIB Repository

I Ketut Artadi dan Dewa Nyoman Rai Asmara Putra, (2009), Pengantar Umum Tentang Alternatif Penyelesaian Sengketa dan Perancangan Kontrak, Denpasar, Skripsi Fakultas Hukum Universitas Udayana

I Made Agus Mahendra Iswara, (2011), "Peranan Mediasi Penal dalam Menyelesaikan Tindak Pidana Kekerasan dalam Rumah Tangga (KDRT) di Polresta Denpasar”, Skripsi, Fakultas Hukum Universitas Udayana

Kornelius Benuf dan Muhamad Azhar, (2020), "Metodologi Penelitian Hukum Sebagai Instrumen Instrumen Mengurangi Permasalahan Hukum Kontemporer", Jurnal Gema Keadilan, Volume 7, Edisi 1.

Nirmala Sari, Diana Haiti dan Ifrani, Mediasi Penal Sebagai Alternatif Penyelesaian Perkara Tindak Pidana Lingkungan Hidup Pada Lahan Basah di Provinsi Kalimantan Selatan, Jurnal Al Adl, Volume VIII Nomor 1, Januari-April 2016.

Yati Nurhayati, (2013) "Perdebatan Metode Normatif dengan Metode Empirik Dalam Penelitian Ilmu Hukum Ditinjau Dari Karakter, Fungsi dan Tujuan Ilmu Hukum", Jurnal Al Adl, Volume 5 Nomor 10.

Yati Nurhayati, (2019) The Finality of Arbitration : The Pros and Cons of The Court's Power To Setting Aside Arbitral Awards In Indonesia, Prosiding International Legal Recontruction in Indonesia Based on Human Rights, Unissula Press.

Yati Nurhayati, 2020. "The Application of Balance idea In Settlement of Doctor Malpractice Case Through Penal Mediation", The 2nd Proceeding "Indonesia Clean of Corruption in 2020, Unissula Press.

\section{Internet}

Detlev Frehsee (Professor of Criminology and Criminal Law, University of Bielefeld, Germany),"Restitution and Offender-Victim Arrangement in German Criminal Law: Development and Theoretical Implications", http://wings.buffalo.edu/law/ bclc/bclr.htm, diakses tanggal 28 Juni 2011

Muhammad Yasin, https://hukumonline.com, Reformasi Peradilan : Peradilan yang Sederhana, Cepat dan Biaya Ringan, diakses pada Tanggal 04 Februari 2018. 